\title{
Comparison of small group discussions and didactic lectures in pharmacology for medical undergraduate students
}

\author{
Anupama Desai, Neeta Banzal* \\ Department of Pharmacology, Surat Municipal Institute of Medical Education and Research (SMIMER), Surat, \\ Gujarat, India
}

Received: 28 September 2021

Revised: 06 October 2021

Accepted: 07 October 2021

*Correspondence:

Dr. Neeta Banzal,

Email:akj01936@yahoo.com

Copyright: $\odot$ the author(s), publisher and licensee Medip Academy. This is an open-access article distributed under the terms of the Creative Commons Attribution Non-Commercial License, which permits unrestricted non-commercial use, distribution, and reproduction in any medium, provided the original work is properly cited.

\begin{abstract}
Background: Conventionally, in most medical colleges, didactic lectures form a major part of teaching, however this method of teaching has many limitations. There has been a paradigm shift in teaching learning methods which now favor enhanced student involvement. Small group discussion (SGD) is one such method which has been frequently compared with didactic lectures. This study aims to compare these two teaching learning methods.

Methods: This was a randomized prospective cross sectional, comparative study carried out with 120 second MBBS students of Pharmacology. The students were randomly divided into two groups. Group A was taught by conventional didactic method and group B learnt the same topic by SGD method. For the next topic there was a crossover. After a week students appeared for a test and were asked to fill a 5-point Likert scale perception analysis form.

Results: The post-test average scores for didactic lecture were $6.42 \pm 2.43$ and for SGD were $6.15 \pm 2.70$ (p value 0.4167 ). About $88 \%$ students agree (50\% strongly agree and 38\% agree) that SGD is motivating, $85 \%$ student agree that SGD is interesting form of learning however $26 \%$ student feel that some student dominated in the SGD and $33 \%$ student felt more comfortable in lectures.

Conclusions: The perception analysis showed that majority of the students found SGD better than didactic lectures in terms of learning, involvement, clearing doubts, increasing self-confidence however analysis of the test scores showed no statistically significant difference amongst the marks obtained after didactic lectures or small group discussion.
\end{abstract}

Keywords: Didactic lecture, Small group discussion, Teaching learning method

\section{INTRODUCTION}

The extensive and exhaustive nature of the medical curriculum makes it essential that medical teachers use the best and most effective methods of teaching to enhance learning in students. Pharmacology is the science dealing with the study of drugs. Broadly divided into pharmacokinetics and pharmacodynamics, it deals with the sources, routes of administration, pharmacological actions, uses, absorption, biotransformation, excretion, adverse effects, and toxicities of drugs. The advent of newer drugs or newer uses of older drugs and even the discontinuation of many drugs previously in use make this subject a very volatile one. ${ }^{1}$ Students and faculty both need to be aware of these changes in order to be good practitioners and teachers respectively. The teaching learning process of this subject too needs to evolve along with its content matter.

The conventional didactic lectures have been in practice for long and have proven relatively effective in teaching. However, the need for more student interaction to encourage self-directed learning is the need of the hour as it helps students to feel more involved in the teaching learning process. One of the methods to increase student involvement is small group discussions which may prove 
beneficial in this scenario. Many studies have compared small group discussions with conventional didactic lectures with varying results. ${ }^{2-4}$ In this study we wish to assess if there is any difference between the two methods in terms of effectiveness and perception. This would eventually help in implementing such methods for the future teaching of various topics.

The aim of the study was to evaluate the effectiveness of small group discussions as a teaching learning method in pharmacology for undergraduate students - to evaluate the effectiveness of small group discussions over conventional didactic lectures; and to evaluate the perception of students regarding small group discussions and conventional didactic lectures.

\section{METHODS}

The study was designed as a prospective cross sectional, comparative study. This study was carried out from October 2018 to February 2019 in the department of pharmacology, SMIMER Medical College, Surat. Approval for carrying out this study was taken from the institutional ethics committee. Initially the faculty was sensitized about the entire project and its process. Their suggestions were taken before finalizing the topics, time slots, and topics to be covered in the sessions. The two topics to be taken for this study were unanimously decided as 'bronchial asthma' and 'peptic ulcer', taking into consideration the nearly equal level of difficulty and number of lectures/SGDs that could be taken. The entire division of lecture schedules and SGDs was predefined to enable smooth implementation of the entire project.

Sample size was second MBBS students coming to department of pharmacology, they were sensitized about the aims and objectives, procedure and ethical aspects of the study. Inclusion criteria were: the students should be of second year MBBS, and should be willing to participate in the study. Out of 130 students of second MBBS, 10 students expressed their inability to be present for all four sessions due to personal reasons. They were allowed to attend whichever session they wished and were excluded from the study. Informed written consent was taken from remaining 120 students. They were randomly divided into two equal groups.

Table 1: Distribution of topic with teaching learning method in the groups.

\begin{tabular}{|lll|} 
Group & $\begin{array}{l}\text { Topic } 1 \text { - peptic } \\
\text { ulcer (session } 1 \\
\text { and 2) }\end{array}$ & $\begin{array}{l}\text { Topic } 2 \text { - bronchial } \\
\text { asthma (session } 3 \text { and } \\
\text { 4) }\end{array}$ \\
\hline A & SGD & Didactic lecture \\
\hline B & Didactic lecture & SGD \\
\hline
\end{tabular}

Topic 1 (session 1 and 2), was conducted as small group discussion for group $\mathrm{A}$ and as conventional didactic lectures for group B. In topic 2 (session 3 and 4) there was a crossover of the two groups.
After one week the students appeared for a multiple-choice questions (MCQ's) and short answer questions (SAQ's) based examination. The examination consisted of 10 MCQs and 5 SAQs each carrying one mark. Students also answered a questionnaire to assess the perception of students toward the two different methods of teaching. A literature review was carried out to find out suitable questionnaire rather than developing one and it was found that the questionnaire used by Verma et al was quite exhaustive and would cover the need of the study, hence was adopted. ${ }^{5}$ The perception based questionnaire had 20 questions and was designed on 5 point Likert scale (strongly agree, agree, undecided, disagree, strongly disagree).

The score obtained by students in the MCQ test were recorded and analyzed for their mean, standard deviation and independent " $\mathrm{t}$ " test. The data of the perception based questionnaire were grouped together as frequency table and were analyzed as percentage of responses. Excel and online Graph Pad prism software were used for carrying out the statistical analysis.

\section{RESULTS}

Table 2 shows the analysis of post-test marks obtained by the students. Mean result of didactic lectures is $6.42 \pm 2.43$ and mean of SGD group is $6.15 \pm 2.70$. There is no statistically significant difference between the test results indicating that there may not be a significant difference in actual learning with the two methods of teaching.

Table 2: Post test scores comparing SGDs with didactic lectures.

\begin{tabular}{|llll|}
\hline Group & $\begin{array}{l}\text { Mean test } \\
\text { scores }\end{array}$ & SD & P value \\
\cline { 1 - 3 } $\begin{array}{l}\text { Didactic lectures } \\
\text { (N=120) }\end{array}$ & 6.42 & \pm 2.43 & $\begin{array}{l}0.4167 \\
\text { (not }\end{array}$ \\
\cline { 1 - 3 } SGD's (N=120) & 6.15 & \pm 2.70 & significant) \\
\hline
\end{tabular}

The results in Table 3 shows that $31 \%$ of students strongly agree and 54\% agree that SGD is an interesting form of learning. 50\% strongly agree that SGD sessions motivated them towards reading and preparing before a session. $90 \%$ students (strongly agree and agree combined) expressed their feeling of involvement throughout the SGD sessions. Similarly large number of students, $65 \%$ agreed that they were able to clear doubts and $67 \%$ agreed that they felt more confident about a topic after SGD.

The result in Table 4 indicate that there were students those who felt otherwise and were not in favor of SGD. $28 \%$ students felt that teaching was not focused in SGDs while $14 \%$ felt fearful of SGD sessions. More than one fourth, $26 \%$ students expressed that some students dominated the SGD sessions. A small number of students $8 \%$ felt that time was wasted in SGD. Around 14\% students felt that they were unable to express their views during SGD. $16 \%$ students were not confident about the knowledge of their colleagues. 
Table 3: Student's perception towards favorable statements about SGD.

\begin{tabular}{|c|c|c|c|c|c|c|c|c|c|c|c|}
\hline \multirow[t]{2}{*}{ Statement } & \multicolumn{2}{|c|}{$\begin{array}{l}\text { Strongly } \\
\text { agree }\end{array}$} & \multicolumn{2}{|c|}{ Agree } & \multicolumn{2}{|c|}{ Undecided } & \multicolumn{2}{|c|}{ Disagree } & \multicolumn{2}{|c|}{$\begin{array}{l}\text { Strongly } \\
\text { disagree }\end{array}$} & \multirow{2}{*}{$\begin{array}{l}\text { Total } \\
\text { responses }\end{array}$} \\
\hline & $\mathbf{N}$ & $\%$ & $\mathbf{N}$ & $\%$ & $\mathbf{N}$ & $\%$ & $\mathbf{N}$ & $\%$ & $\mathbf{N}$ & $\%$ & \\
\hline $\begin{array}{l}\text { SGD was an interesting form of learning } \\
\text { for me }\end{array}$ & 37 & 31 & 65 & 54 & 8 & 7 & 8 & 7 & 2 & 2 & 120 \\
\hline SGD helped me in self learning & 47 & 39 & 59 & 49 & 8 & 7 & 3 & 3 & 3 & 3 & 120 \\
\hline $\begin{array}{l}\text { SGD motivated me to read and prepare } \\
\text { before the session }\end{array}$ & 60 & 50 & 45 & 38 & 9 & 8 & 5 & 4 & 0 & 0 & 119 \\
\hline $\begin{array}{l}\text { I was involved throughout the SGD } \\
\text { sessions }\end{array}$ & 45 & 38 & 62 & 52 & 6 & 5 & 6 & 5 & 0 & 0 & 119 \\
\hline $\begin{array}{l}\text { I feel confident about the topic after the } \\
\text { SGD sessions }\end{array}$ & 29 & 24 & 51 & 43 & 25 & 21 & 11 & 9 & 4 & 3 & 120 \\
\hline SGD sessions helped me in learning & 36 & 30 & 68 & 57 & 7 & 6 & 7 & 6 & 2 & 2 & 120 \\
\hline $\begin{array}{l}\text { SGD's helped me to clear my doubts } \\
\text { better than lectures }\end{array}$ & 29 & 24 & 49 & 41 & 25 & 21 & 10 & 8 & 6 & 5 & 119 \\
\hline $\begin{array}{l}\text { I would like to have more such SGD } \\
\text { sessions in the future }\end{array}$ & 38 & 32 & 47 & 39 & 20 & 17 & 10 & 8 & 4 & 3 & 119 \\
\hline
\end{tabular}

Table 4: Student's perception towards unfavorable statements about SGD.

\begin{tabular}{|c|c|c|c|c|c|c|c|c|c|c|c|}
\hline \multirow[t]{2}{*}{ Statement } & \multicolumn{2}{|c|}{$\begin{array}{l}\text { Strongly } \\
\text { agree }\end{array}$} & \multicolumn{2}{|c|}{ Agree } & \multicolumn{2}{|c|}{ Undecided } & \multicolumn{2}{|c|}{ Disagree } & \multicolumn{2}{|c|}{$\begin{array}{l}\text { Strongly } \\
\text { disagree }\end{array}$} & \multirow{2}{*}{$\begin{array}{l}\text { Total } \\
\text { responses }\end{array}$} \\
\hline & $\mathbf{N}$ & $\%$ & $\mathbf{N}$ & $\%$ & $\mathbf{N}$ & $\%$ & $\mathbf{N}$ & $\%$ & $\mathbf{N}$ & $\%$ & \\
\hline $\begin{array}{l}\text { I was unable to express my views in SGD } \\
\text { sessions }\end{array}$ & 1 & 1 & 15 & 13 & 8 & 7 & 60 & 50 & 36 & 30 & 120 \\
\hline $\begin{array}{l}\text { I felt some students dominated the SGD } \\
\text { sessions }\end{array}$ & 8 & 7 & 23 & 19 & 8 & 7 & 48 & 41 & 31 & 26 & 118 \\
\hline $\begin{array}{l}\text { I was not confident about the knowledge } \\
\text { of my colleagues in the SGD sessions }\end{array}$ & 1 & 1 & 18 & 15 & 27 & 23 & 53 & 45 & 18 & 15 & 117 \\
\hline $\begin{array}{l}\text { I felt time was wasted in the SGD } \\
\text { sessions }\end{array}$ & 4 & 3 & 6 & 5 & 9 & 8 & 56 & 47 & 43 & 36 & 118 \\
\hline I felt teaching was not focused in SGD's & 6 & 5 & 27 & 23 & 23 & 19 & 49 & 42 & 13 & 11 & 118 \\
\hline I feel fearful of SGD sessions & 3 & 3 & 13 & 11 & 17 & 14 & 57 & 48 & 28 & 24 & 118 \\
\hline
\end{tabular}

Table 5: Student's perception towards didactic lectures.

\begin{tabular}{|c|c|c|c|c|c|c|c|c|c|c|c|}
\hline \multirow[t]{2}{*}{ Statement } & \multicolumn{2}{|c|}{$\begin{array}{l}\text { Strongly } \\
\text { agree }\end{array}$} & \multicolumn{2}{|c|}{ Agree } & \multicolumn{2}{|c|}{ Undecided } & \multicolumn{2}{|c|}{ Disagree } & \multicolumn{2}{|c|}{$\begin{array}{l}\text { Strongly } \\
\text { disagree }\end{array}$} & \multirow{2}{*}{$\begin{array}{l}\text { Total } \\
\text { responses }\end{array}$} \\
\hline & $\mathbf{N}$ & $\%$ & $\mathbf{N}$ & $\%$ & $\mathbf{N}$ & $\%$ & $\mathbf{N}$ & $\%$ & $\mathbf{N}$ & $\%$ & \\
\hline $\begin{array}{l}\text { I felt more comfortable in lectures than } \\
\text { in SGD's }\end{array}$ & 18 & 15 & 21 & 18 & 39 & 33 & 33 & 28 & 6 & 5 & 117 \\
\hline $\begin{array}{l}\text { I was able to understand the topic better } \\
\text { in lectures }\end{array}$ & 8 & 7 & 32 & 27 & 36 & 30 & 36 & 30 & 8 & 7 & 120 \\
\hline I felt lectures were monotonous & 22 & 19 & 32 & 28 & 30 & 26 & 25 & 22 & 6 & 5 & 115 \\
\hline
\end{tabular}

Table 6: Student's perception towards facilitators in SGD.

\begin{tabular}{|c|c|c|c|c|c|c|c|c|c|c|c|}
\hline \multirow[t]{2}{*}{ Statement } & \multicolumn{2}{|c|}{$\begin{array}{l}\text { Strongly } \\
\text { agree }\end{array}$} & \multicolumn{2}{|c|}{ Agree } & \multicolumn{2}{|c|}{ Undecided } & \multicolumn{2}{|c|}{ Disagree } & \multicolumn{2}{|c|}{$\begin{array}{l}\text { Strongly } \\
\text { disagree }\end{array}$} & \multirow{2}{*}{$\begin{array}{l}\text { Total } \\
\text { responses }\end{array}$} \\
\hline & $\mathbf{N}$ & $\%$ & $\mathbf{N}$ & $\%$ & $\mathbf{N}$ & $\%$ & $\mathbf{N}$ & $\%$ & $\mathbf{N}$ & $\%$ & \\
\hline The facilitator was helpful & 31 & 26 & 58 & 50 & 20 & 17 & 7 & 6 & 1 & 1 & 117 \\
\hline $\begin{array}{l}\text { I feel the facilitator should interact more } \\
\text { in such sessions }\end{array}$ & 21 & 18 & 41 & 35 & 21 & 18 & 27 & 23 & 7 & 6 & 117 \\
\hline I was disturbed by the facilitator & 2 & 2 & 5 & 4 & 14 & 12 & 55 & 47 & 41 & 35 & 117 \\
\hline
\end{tabular}

More than one third, around 34\% students preferred lectures over SGD and stated that they were able to understand the topic better in lectures. 33\% students agreed that they feel more comfortable in lectures however just 
short of half, $47 \%$ students felt that didactic lectures were monotonous (Table 5).

There were a few questions seeking the perception of students regarding the role of facilitator during SGD. Around three fourth, $76 \%$ student felt that facilitators were helpful however more than half, $53 \%$ students were of the opinion that facilitators should interact more during SGD sessions. There was a small number of students, $6 \%$ who felt disturbed by the facilitator (Table 6).

Regarding the perception of the students for holding of SGD in future, a good number of students, $71 \%$ expressed their opinion in favor of having SGD session as preferred mode of teaching learning method.

\section{DISCUSSION}

As far as the quantitative results are concerned, this study has shown that there is no statistically significant difference in the test scores between didactic lectures and SGD groups. This is in contrast to a study done by Savkar et al where test results post SGD were significantly better than didactic lectures. ${ }^{6}$ Other studies conducted by Chandelkar et al, and Padugupati et al also noticed similar improvement in post SGD result compared to didactic lecture group. ${ }^{7,8}$ In this current study the lack of significance in SGD group and didactic lecture group may be due to sudden change in pattern of teaching learning in students who are used to didactic lectures. This result of test scores is similar to a study done by Arias in which there is no significant difference in written test scores in the two methods. ${ }^{9}$

The perception analysis in this study however shows that students find SGD a more interesting (85\%), motivating towards self-learning (88\%), more involving $(90 \%)$, helpful in clearing doubts $(65 \%)$. Similar positive findings were observed by Padugupati et al in a study carried out on $1^{\text {st }}$ year MBBS students $(\mathrm{N}=140)$ in which $100 \%$ student found it interesting and motivating and $95.7 \%$ helpful in clearing doubts. ${ }^{8}$ In another study carried out by Bhutani et al $66.2 \%$ students found it interesting. ${ }^{2}$

The challenges faced by some of the students in SGD like being unable to express their views (14\%), teaching was not focused $(28 \%)$, wastage of time $(8 \%)$, not confident about knowledge of colleagues' information (16\%), fearful (14\%) compare well with the study carried out by Majhi et al unfocussed teaching $(4.5 \%)$, waste of time (7\%), uncertainty about colleagues' knowledge (8.9\%), stressful $(8.9 \%){ }^{10}$

In this study $71 \%$ student agreed that they would like more such sessions in future. These results are similar to other studies done by Joshi et al which show a preference of students towards SGD's as opposed to conventional didactic lectures. ${ }^{11}$ In this present study $34 \%$ students expressed a preference toward didactic lecture, while $47 \%$ found didactic lectures monotonous. This shows that there is a need for teachers to make even didactic lectures more interactive to prevent monotony. This has been seen in other studies, Chilwant and Miller et al, which have clearly demonstrated better performance of students attending interactive lectures compared to conventional didactic lectures. ${ }^{12,13}$

The present study has limitation as it was done for only second MBBS students and for limited number of sessions. Further similar studies covering more students, faculty and more sessions would be needed to generalize the finding of this study.

\section{CONCLUSION}

The study showed that there was no significant difference in quantitative results between didactic lectures vis a vis small group discussion. However, the perception of students is clearly in favor of small group discussion in place of didactic lectures. SGDs definitely appear to be more acceptable to students as an interesting teaching learning method, though there are challenges to conduct SGDs and it demands prior preparation on the part of the student as well as on the part of the facilitator. There is a clear need to make didactic lectures more interactive and interesting to prevent monotony and boredom.

\section{ACKNOWLEDGEMENTS}

Authors would like to thank the entire department for their cooperation, and also the students who had agreed to take part in the study without any hesitation.

Funding: No funding sources

Conflict of interest: None declared

Ethical approval: The study was approved by the Institutional Ethics Committee

\section{REFERENCES}

1. Brunton L, Chabner B, Knollman B. Goodman and Gilman's Pharmacological Basis of Therapeutics. 12th ed. China: Mc Graw Hill Companies, Inc. 2011.

2. Bhutani N, Arora D, Bhutani N. A Comparison of Effectiveness of Interactive Methods over Traditional Methods in Teaching Biochemistry to Undergraduate Medical Students. Int J Rec Innov Med Clin Res. 2020;2(2):57-63.

3. Sahu PK, Nayak S, Rodrigues V. Medical students' perceptions of small group teaching effectiveness in hybrid curriculum. J Educ Health Promot. 2018;7:30.

4. Bhattacharya N, Habib N, Rashid M, Sugathan S, Afrose T, Kottakal EN. Combination of SGT (small group teaching) and PAL (peer assisted learning) approach to facilitate learning among MBBS students from a private university in Malaysia during preclinical years. Malaysian J Public Health Med. 2020;20(3):79-84. 
5. Verma L, Chetan KR, Bansal A. Comparison of Small Group Discussions and Didactic Lectures in Forensic Medicine. Indian J Legal Med. 2019;1(2):49-54.

6. Savkar MK, Mariswamy V, Gangadhar M. Comparison between didactic lectures and small group discussions among second year medical undergraduates in pharmacology. Int J Basic Clin Sci. 2016;6(2).

7. Chandelkar UK, Rataboli PV, Kulkarni MS. Assessment of impact of small group teaching over didactic lectures and self-directed learning among second year BDS students in general and dental pharmacology in Goa medical college. Pharmacol Online. 2014;3:51-7.

8. Padugupati S, Joshi KP, Yamini D, Chary RSS, Sarma DVHS. Educational outcomes of small group discussion versus traditional lecture among first year undergraduate medical students. J Educ Technol Health Sci. 2017;4(3):93-6.

9. Arias A, Scott R, Peters OA, McClain E, Gluskin AH. Educational Outcomes of Small-Group Discussion Versus Traditional Lecture Format in Dental Students' Learning and Skills Acquisition. J Dent Educ. 2016;80(4):459-65.
10. Majhi P, Sulakhe R. Didactic lectures and small group discussions among undergraduate students in a medical college - A comparative study. J Educational Res Med Teach. 2014;2(2):10-1.

11. Joshi KP, Robins M, Reddy MY. Perception and preferences of teaching and learning methods in community medicine: a cross sectional study. Int J Community Med Public Health. 2018;5(7):2821-4.

12. Chilwant KS. Comparison of two teaching methods, structured interactive lectures and conventional lectures. Biomed Res. 2012;23(3):363-6.

13. Miller CJ, McNear J, Metz MJ. A comparison of traditional and engaging lecture methods in a large, professional-level course. Adv Physiol Educ. 2013;37:347-55.

Cite this article as: Desai A, Banzal N. Comparison of small group discussions and didactic lectures in pharmacology for medical undergraduate students. Int J Basic Clin Pharmacol 2021;10:1245-9. 